Vol 3, No 1 (2020): Stadium - Hungarian Journal of Sport Sciences

https://doi.org/10.36439/SHJS/2020/1/5423

\title{
VÁZIZOMSÉRÜLÉS KEZELÉSEK JELENLEGI MÓDJAINAK ÁTTEKINTÉSE
}

\author{
OVERVIEW OF THE CURRENT METHODS OF SKELETAL MUSCLE INJURY TREATMENT
}

\author{
Gyenes Dominik ${ }^{1}$, Budai Zsófia ${ }^{1}$, Sarang Zsolt ${ }^{1}$ \\ 1 Biokémiai és Molekuláris Biológiai Intézet, Általános Orvostudományi Kar, Debreceni Egyetem, Debrecen, \\ Magyarország
}

\section{Összefoglaló}

A harántcsíkolt izomszövetből felépülő vázizmok akaratlagos összehúzódásai a test mozgásait okozzák és jól irányíthatók. A vázizom egyik legjellegzetesebb tulajdonsága, hogy nagyfokú in vivo és in vitro regenerációs képességgel rendelkezik, viszont nagyobb mennyiségú izomvesztés esetén a regenerációs folyamat kimerül, intervenciós támogatást igényel. Ebből következik, hogy az izomsérülés folyamatos kihívást jelent a klinikum számára. Az elmúlt században, különösen az utóbbi néhány évtizedben számos technikát dolgoztak ki az izomregeneráció elősegítése érdekében, ideértve a különböző mütéti technikákat, a fizikoterápiát, a biológiai anyagokat, az izomszövettenyésztést, krioterápiát, mágneses mező alkalmazását, valamint a sejtterápiát. Ugyanakkor továbbra is nagy igény mutatkozik új módszerek és anyagok kifejlesztésére, melyek elösegítik a vázizom megfelelő érését és a funkcionális regenerációt. Ebben a tanulmányban átfogó képet adunk az izomszövetveszteség epidemiológiájáról, rávilágítunk a klinikai kezelés aktuális stratégiáira, és megvitatjuk az izomregeneráció új módszereit, a jövőbeli klinikai átalakulásuk kihívásait.

Kulcsszavak: izomsérülés, izomregeneráció, intervenció

\begin{abstract}
Voluntary contractions of skeletal muscle made up of striated muscle tissue cause body movements and are well controlled. One of the most characteristic features of skeletal muscle is its high in vivo and in vitro regeneration capacity, but with greater muscle loss, the regeneration process is exhausted and requires intervention support. It follows that muscle injury is a constant challenge for the clinic. In the last century, especially in the last few decades, a number of techniques have been developed to promote muscle regeneration, including various surgical techniques, physical therapy, biomaterials, muscle tissue cultivation, cryotherapy, magnetic field application and cell therapy. At the same time, there is still a great need to develop new methods and materials that promote skeletal muscle improvement and functional regeneration. In this study we give a comprehensive picture of the epidemiology of muscle tissue loss, highlight current strategies for clinical management, and discuss new methods of muscle regeneration and the challenges of their future clinical transformation.
\end{abstract}

Keywords: muscle injury, muscle regeneration, intervention 


\section{ELMÉLETI HÁTTÉR}

A vázizom az emberi test egyik legtömegesebb szövete (1.ábra). A teljes testsúly $40-45 \%$ -át teszi ki, és a mozgáshoz szükséges erőt generálja. Sérülés esetén egy bizonyos mértékig a vázizom képes a sérült szövetet regenerálni. A regenerációs kapacitás túllépése esetén az izomszövet nem képes teljes mértékben megújulni. A tartós funkcionális károsodással járó vázizomvesztést „térfogati izomvesztésnek” (VML) nevezzük. Ez jelentősen befolyásolhatja a betegek életminőségét azáltal, hogy beszűkíti a mozgásszervi rendszer működését [GROGAN - HSU, 2011].

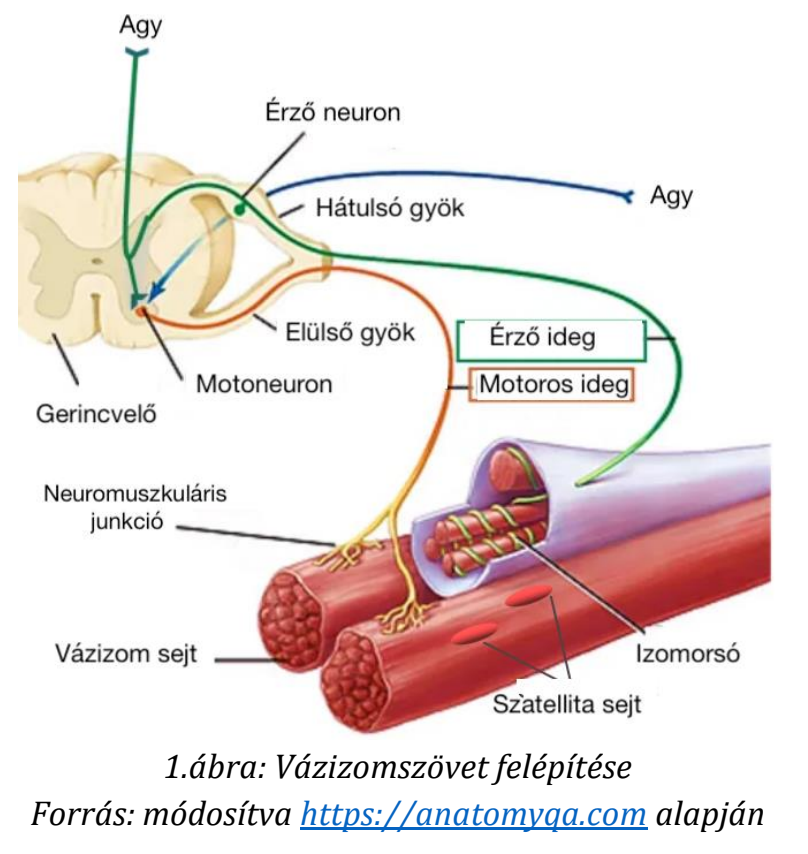

A vázizom-sérülések gyakori okai lehetnek nagy energiájú közlekedési balesetek, robbanási trauma, harci sérülések, műtét utáni és ortopédiai állapotok (pl. kompartmentszindróma vagy daganat-eltávolítás), zúzódásos sérülések, amelyek akut izomszövetveszteséghez vezetnek. A sport során szerzett sérülések kb. 35-55\%-ban az izomrost szintjén következik be károsodás. Azok a sérülések, amelyek az adott izomtömeg legalább 20\% -át károsítják, rekonstruktív műtéti eljárásokra szorulnak [TURNER- BADYLAK, 2012]. A progresszív izomvesztés metabolikus rendellenességek vagy öröklött genetikai betegségek, például Duchenne és Becker izomsorvadás következményei [SAURE, 2017]. Az izomatrófia perifériás idegsérüléseket, krónikus vesebetegséget, cukorbetegséget és szívbetegséget okozhat [KALYANI, 2014]. Az izomtömeg akár 20\% -os veszteséget is képes kompenzálni a vázizmok nagy alkalmazkodóképességének köszönhetően. Ezen küszöböt túllépve a funkcionális károsodás elkerülhetetlen, és súlyos fogyatékossághoz, valamint esztétikai problémákhoz vezethet, ezért ezek a betegek sürgősen terápiás beavatkozásra szorulnak.

Az izomregeneráció az izom őssejtek (szatellita sejtek, SC) az intersticiális sejtek és az erek heterogén populációján alapszik és főként az extracelluláris mátrix (ECM) fehérjék és a szekretált faktorok által szabályozott. Az izomtömeget a fehérjeszintézis és a fehérje 
lebontás egyensúlya határozza meg. A VML legtöbb esetében a vázizmok regenerációs képessége akadályozott, mivel a regenerációhoz szükséges SC, perivaszkuláris őssejtek és a bazális alapréteg fizikailag sérül [CHARGÉ - RUDNICKI, 2004]. A denerváció révén aktiválódnak a fehérje lebontási útvonalak. Ennek következményeképpen a fehérje lebomlási sebessége meghaladja a fehérjeszintézist, ami hozzájárul az izomatrófiához, amelyet az izom tömegének és az izomrostok átmérőjének fokozatos csökkenése kísér. A revaszkularizáció folyamata általában sérült. A következményes iszkémiás állapotok elősegítik a fibroblaszt-proliferációt, a fibrózist és a fibrotikus hegszövet kialakulását, ami az izom további degenerációjához vezet. Az ECM összetétele és mennyisége a hegszövetekben a miogenezis, az izommúködés és a megújulás számos aspektusát befolyásolja [GRZELKOWSKA - KOWALCZYK, 2016]. Súlyosan korlátozhatja a mozgást, ezáltal súlyosbíthatja az izomszövet veszteség következményeit. Krónikus izomvesztés során, jellemzően a fibrózis jelenti a fő problémát. A hosszantartó gyulladásos folyamatok az ECM megváltozott előállításához és ennek következtében fibrózis és hegszövet kialakulásához vezetnek. Ezt a hegképződést csökkenthetjük például 5-fluoro-uracil (5FU) és Bleomycin injekcióval, amelyek antagonizálják a fibroblaszt-proliferációt és angiogenezist, vagy lézerkezeléssel, kontraktúra felszabadításával és funkciójavítással 612 hónapos kezelés után [SERRANO - MUÑOZ-CÁNOVES, 2010; TAUDORF, 2015]. A hegképződés csökkentése azonban nem elegendő az izomszövet javulásának és regenerációjának elősegítéséhez. Ez kulcsfontosságú feladatot jelent az izomszövet nagyobb mennyiségének pótlására vagy regenerálására irányuló klinikai és kutatási tevékenységnek.

\section{MÓDSZER}

\section{ADATGYÜJTÉS}

Munkánk során a Google és Pubmed (https://www.ncbi.nlm.nih.gov/pubmed/) oldalakon gyűjtöttükizomsérülések kezelésével és izomregenerációt elősegítő módszerekkel kapcsolatos cikkeket. Az adatgyüjtés során hagyományos sebészeti eljárások mellett a legújabb alternatív, illetve gén- és őssejterápiás módszereket is igyekeztünk feldolgozni. 


\section{AZ IZOMSZÖVET-VESZTESÉG KEZELÉSÉNEK JELENLEGI MÓDSZEREI A KLINIKUMBAN}

\section{SEBÉSZETI TECHNIKÁK}

A VML műtéti kezelése elsősorban hegszövet eltávolítást és/vagy izomátültetést foglal magában. Az autológ izomtranszfert általában olyan klinikai helyzetben hajtják végre, amikor nagy kiterjedésű az izomvesztés trauma, daganatos rezekció vagy olyan idegsérülés következtében, ami rontja a motoros funkciót [STEVANOVIC et al., 2016]. A sebészek az egészséges izmot a donor sérülés nélküli részeiről távolítják el, hogy helyreállíthassák az elveszett vagy kóros funkciót. A legnépszerűbb autológ izmok a latissimus dorsi izom és a gracilis izom. Noha a funkcionális izomlemezekkel hatékony funkcionális javulást lehet elérni, jelentős fokú donor morbiditást és nem megfelelő beidegződést okoznak. Ezen túlmenően a rekonstruktív műtétek mintegy $10 \%$-a teljes graft meghibásodást okoz olyan komplikációk miatt, mint például fertőzés és nekrózis [BIANCHI et al., 2009].

\section{FIZIKOTERÁPIA}

A testmozgás gátolja a vázizom tömegének csökkenését. Ebből következik, hogy a műtéti technikák mellett a fizikoterápia egy nem invazív/minimálisan invazív módszer az izomszövet helyreállításának és regenerációjának elősegítésére. Különös mértékben használható sérülések és izomszövet-átadás utáni rehabilitációra, vagy krónikus izomvesztés kezelésére.

A fizikai rehabilitáció célja a megmaradt izmok erősítése. Kimutatták, hogy ez felgyorsítja az izmok gyógyulását/regenerálódását az immunválasz modulálásával, a növekedési faktorok felszabadításával, az érrendszer kialakulásának elősegítésével és a hegképződés csökkentésével [BRUTSAERT et al., 2002]. A nem helyreállított VML-sérült izmok funkcionális teljesítménye jelentősen javítható az „önkéntes kerékfutás” formájában végzett fizikai rehabilitációval [AURORA et al., 2014]. Úgy tűnik, hogy a testmozgás képes az inzulin-szerű növekedési faktor 1 (IGF-1) jelátviteli út szabályozására és csökkenti az izomfejlődést gátló miosztatin mennyiségét az állatok és az emberek izomszövetében, ezáltal megakadályozva az izmok atrófiáját [KOPPLE et al., 2007].

A fizikoterápia valóban javíthatja az izmok regenerációját; azonban nem képes megkönnyíteni az izom regenerálódását a VML területein. Ezenkívül a súlyos betegségben vagy sérülésben szenvedő betegek gyakran nem képesek folyamatos testmozgást végezni, ami korlátozza a fizikoterápiát, ezáltal a VML kezelését. 


\section{AKUPUNKTÚRA}

Az akupunktúra a hagyományos kínai orvoslás egyik ága, amelyet világszerte széles körben használnak különféle betegségek kezelésére. Kimutatták, hogy az elektromos akupunktúrás kezelés elnyomja a miosztatin expresszióját, ami a SC proliferációjához és a vázizom javulásához vezet [TAKAOKA et al., 2007]. Az akupunktúra és az alacsony frekvenciájú elektromos stimuláció (Acu-LFES) elősegítheti az izmok regenerálódását és megakadályozhatja az izomvesztést az izmok összehúzódásának stimulálása révén [SU et al., 2015]. Alkalmas lehet olyan súlyos betegségben szenvedő páciensek számára is, akik nem képesek testedzést végezni. Az Acu-LFES alkalmazása krónikus vesebetegség által kiváltott diabéteszes miopátia és izomvesztés kezelésére az izom jó irányú funkcionális javulását mutatta [HU et al., 2015].

\section{BIOLÓGIAI ANYAGOK}

Az ECM fehérjékből álló biológiai anyagokat gyakran használják az izomregenerációt segítő orvoslásban és a szöveti rekonstrukciót célzó sebészi eljárásokban. Ezen anyagok elősegíthetik a VML javulását azáltal, hogy szerkezeti és biokémiai támaszt biztosítanak. Az izomvesztés mennyiségének csökkentése érdekében számos szövetből származó biológiai anyagot teszteltek állatmodellen, és a klinikumban alkalmazzák őket. A xenogénextracelluláris mátrixot és az autológ szövetet egyaránt felhasználják az izomfunkció helyreállítására. Sertés vékonybél szubmukózából származó ECM-et alkalmazzák például hasi muszkuloszkeletális károsodások kezelésére.

Az allograft vagy xenogén biológiai anyagok azonban továbbra is kóros immunválaszt provokálhatnak, fennállhat a fertőző betegség terjedésének veszélye. Ebből adódik a klinikai szükség új, biztonságosabb stratégiák kidolgozására.

\section{FEJLŐDŐ TECHNIKÁK AZ IZOMREGENERÁCIÓ, IZOMSZÖVETTENYÉSZTÉS FOLYAMATÁBAN}

A fennmaradó klinikai problémák kezelése, az izomszövettenyésztés, -regeneráció új stratégiáinak feltárása jelentős mértékű ambíciót jelentett a kutatásban. Míg a szövet bioinformatikai vizsgálatának célja az összetett izomszerkezetek in vitro létrehozása a hiányzó izmok későbbi beültetése és pótlása céljából, addig a szövetregenerációs megközelítések olyan szövetszerű anyagokat fejlesztenek ki, amelyek beültethetők az izomképződés fokozására a fennmaradó in vivo szövetből [WANG et al., 2014]. Mindkét megközelítés elsősorban biológiai anyagok, sejtek és molekuláris jelátviteli útvonalak kombinációjára támaszkodik, kissé másra helyezve a hangsúlyt.

\section{BIOLÓGIAI ANYAGON ALAPULÓ TECHNIKÁK}

A biológiai anyagok kémiai és fizikai támaszként szolgálhatnak az átültetett sejtek vagy a gazdaszervezet izomsejtjei számára, ezáltal javítva a túlélést, elősegítve funkcionális 
érésüket, megvédve őket az idegen test reakcióitól [CEZAR - MOONEY, 2015]. A biológiai anyagokat különféle szövetregenerációban használja a klinikum, az elmúlt évtizedben csontváz-izom VML sérülési modellekben vizsgálták. Elsősorban természetes polimerekből, szintetikus polimerekből vagy ECM-ből készülnek, és úgynevezett „mikrokörnyezeti rést" próbálnak létrehozni a rezidens sejtek viselkedésének kedvező befolyásolására (2.ábra).

A természetes polimereket, például az alginátot, a kollagént és a fibrint széles körben alkalmazzák vázizomépítésben. Ezen anyagok belső bioaktív jelátviteli útvonalakon keresztülfejtik ki kedvező hatásukat. Az alginát gélekről kiderült, hogy maximalizálják a mioblaszt proliferációt és differenciálódást [BOONTHEEKUL et al., 2006]. A fagyasztva szárított kollagén polimerek megkönnyítették a miotubusok integrálódását egy nagyobb izomsérülés során. A kollagén a szükséges növekedési faktorokat is képes biztosítani az izomsejtek migrációjának fokozása érdekében. A fibrin gélekről bebizonyosodott, hogy elősegítik a mioblaszt túlélését és az izomrosttá történő differenciálódást a szövetekbe helyezést követően. Azt is kimutatták, hogy mikroszálas felépítésű fibrin polimerek kedvező hatással vannak a VML gyógyulására egér modellekben [GRASMAN et al., 2015].

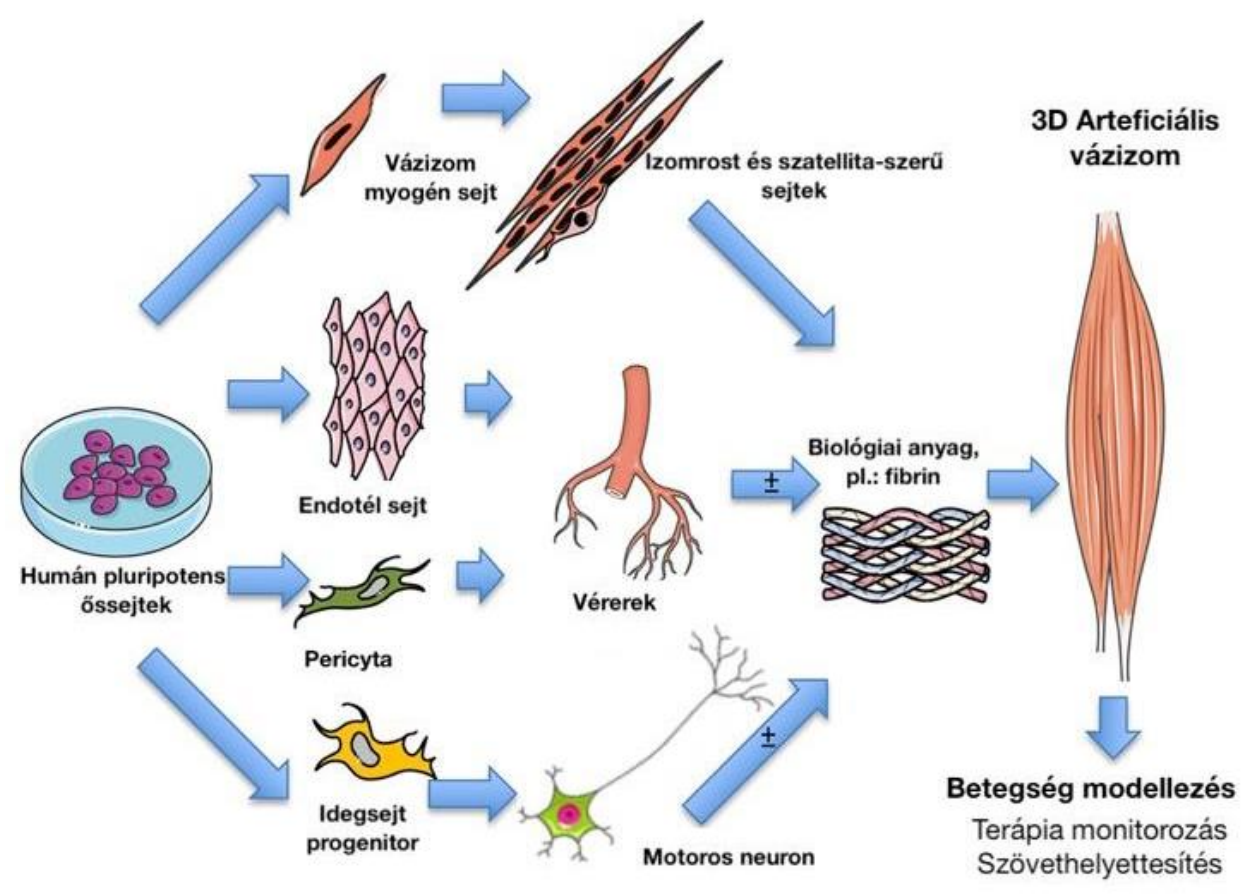

2.ábra:

In vitro izomszövettenyésztés biológiai polimer beágyazott ôssejtekből Forrás: módosítva https://ars.els-cdn.com alapján

Mivel a természetes polimerek csak korlátozott mechanikai merevséggel rendelkeznek és könnyen lebonthatók, a csontváz izmainak regenerálására különféle szintetikus anyagokat, például politejsav (PLA) és poliglikolsav (PGA) származékokat is alkalmaznak [GUEX et al., 2013]. Ezen felül a szintetikus anyagokat úgy lehet tervezni, hogy 
megkönnyítsék a növekedési faktorok szabályozott felszabadulását az izmok regenerációjának indukálása céljából. A fő hátrányok közé tartozik a természetes polimerekhez viszonyított gyengébb sejt-affinitás, valamint az idegen test reakció stimulálása a polimer vagy annak bomlástermékei ellen, valamint a sejtmigráció gátlása és a sejt-sejt közötti kommunikáció romlása

$\mathrm{Az}$ izomszövet regenerációjának javítása érdekében a biológiai anyagok in vivo mikrokörnyezete ideális esetben a natív szövetekét utánozza, ezáltal megkönnyíti az újjáépítést [TURNER et al., 2010]. A VML javításának vonzó megközelítése egy olyan sejtektől megfosztott, decellularizált biológiai anyag átültetése, amely magához vonzza a miogenezishez szükséges sejteket a gazdaszervezetből. Ezért vizsgálják olyan gyakran az izom eredetű ECM anyagokat. Ezek pótolják a hibát és ideiglenesen helyreállítják a morfológiát. A beültetés után ezek a mátrixok a csontvelőből származó mezenhimális őssejtekkel (MSC) is kitölthetők. Ez a dúsított mátrix több eret fejleszt, és több izomrost regenerálódik, mint „hagyományos” ECM esetében. Kimutatták, hogy a decellularizált vázizommátrixból származó hidrogélek patkány iszkémiás végtagjába injektálva elősegítik a vázizom mioblasztok proliferációját [DEQUACH et al., 2012]. Alternatív módszerek közé tartozik az aprított vázizomszövet felhasználása, amelyet emberben még nem hajtottak végre, viszont kimutatták, hogy jobb izomregeneráció várható tőle, mint a devitalizált biológiai anyagoktól. $\mathrm{Az}$ in vitro izomszövet-tervezéshez patkány mioblasztokat előzetesen kondicionáltak egy bioreaktorban lévő sertéshólyag acelluláris mátrixon, majd egerek sérült izmába adták be az izomszövet helyreállításának céljából [TURNER et al., 2010].

\section{SEJT-ALAPÚ TECHNIKÁK}

Az izomrostok regenerálódása sejt-közvetített folyamat, mely megalapozta a sejtekre alapozott regenerációs módok vizsgálatát. Az izomvesztés kezelésére használt sejttípusok elsősorban a mioblasztok, SC-k, mezoangioblasztok, periciták és a MSC [LEE et al., 2005]. A legjobban jellemezhető őssejt a SC. Az SC-k nagymértékben hozzájárulnak az új izomrostok kialakulásához. Egerekbe transzplantált SC-k rendkívül hatékonyan regenerálódtak az elsorvadt izomban és javították az izmok összehúzódó funkcióját [CERLETTI et al., 2008]. Sajnos az SC-k in vitro felszaporítása jelentősen csökkenti azok regenerációképességét. A mioblasztokat az izomszövet hibáinak rekonstruálására használják különféle biológiai anyagok segítségével. Kimutatták, hogy funkcionálisan integrálódnak a gazdaszervezet meglévő izomzatába. Nagyobb számú mioblaszt izomba történő injekciózása ígéretes eredményeket mutatott a disztrofindeficiens modellek kezelése során [MILLER et al., 1997]. Mezoangioblasztokat és pericitákat vizsgáltak izomsorvadás kezelésére, amelyekről igazolódott, hogy növelik az izomerőt [SAMPAOLESI et al., 2006].

Az őssejt-alapú terápiák figyelemre méltó terápiás eredményekkel szolgálnak az izmok atrófiájának csökkentésében és a regeneráció elősegítésében. Az őssejtterápia (például köldökzsinórvér őssejt-transzplantáció) pozitív eredményeket mutatott a Duchenne izomsorvadás kezelésében [ZHANG et al., 2005]. A vádli-injektálást követő biopszia 
emelkedett mioblaszt számot mutatott, valamint a karok és a lábak funkcionális javulásáról számoltak be a fizikai vizsgálatot követően.

\section{MOLEKULÁRIS JELÁTVITELEN ALAPULÓ TECHNIKÁK}

Az ECM összetétele mellett a stimuláló és gátló növekedési faktorok is képes befolyásolni a vázizmok regenerációját. Ezen növekedési faktorokat biológiai anyagok felszínére helyezve célzott módon a sérülés területére juttathatók. Kimutatták, hogy a vaszkulárisendoteliális növekedési faktor (VEGF) és IGF-1 tartós expressziója fokozza a miogenezist, elősegíti az angiogenezist és az izomképződést [RYBALKO et al., 2015]. A fibrin polimer anyagokra felvitt hepatocita növekedési faktor gyors felszabadulása elősegítette a funkcionális izomszövet átalakulását és elősegítette a vázizom regenerálódását egér modellekben [GRASMAN et al., 2015].

A szarkopénia (progresszív izomleépülés), mint az egyik leggyakoribb izombetegség patogenezisének kutatása különböző molekuláris útvonalakat derített fel. A legígéretesebb célok között szerepel az anti-miosztatin alkalmazása. [SAUL - KOSINSKY, 2017].

A spinális muszkuláris atrófia (SMA) a survival motor neuron 1 (SMN1) gén mutációiból származik, ami gyakran a mindenütt jelenlévő SMN protein hiányát eredményezi. Ezért az egyik legígéretesebb stratégia az SMN szintjének növelése [PARENTE - CORTI, 2018]. A Nusinersen egy antiszenszoligonukleotid gyógyszer, mely a hibás gént ugyan nem pótolja, de egy ahhoz nagyon hasonló génszakaszon kifejtett hatásával a lehetőségekhez mérten korrigálja a hibát, így megemelve működőképes fehérje termelődését. A készítmény hatása átmeneti, de rendszeres adása enyhíti a tüneteket és javítja a motoros funkciókat (3.ábra) [FINKEL et al., 2016]. Ezzel szemben a ZOLGENSMA egy olyan génterápiás kezelés, amely a sérült gént helyreállítja a szervezetben és 2 éves kor alatt egyszeri adása is gyógyítja az SMA-t. 


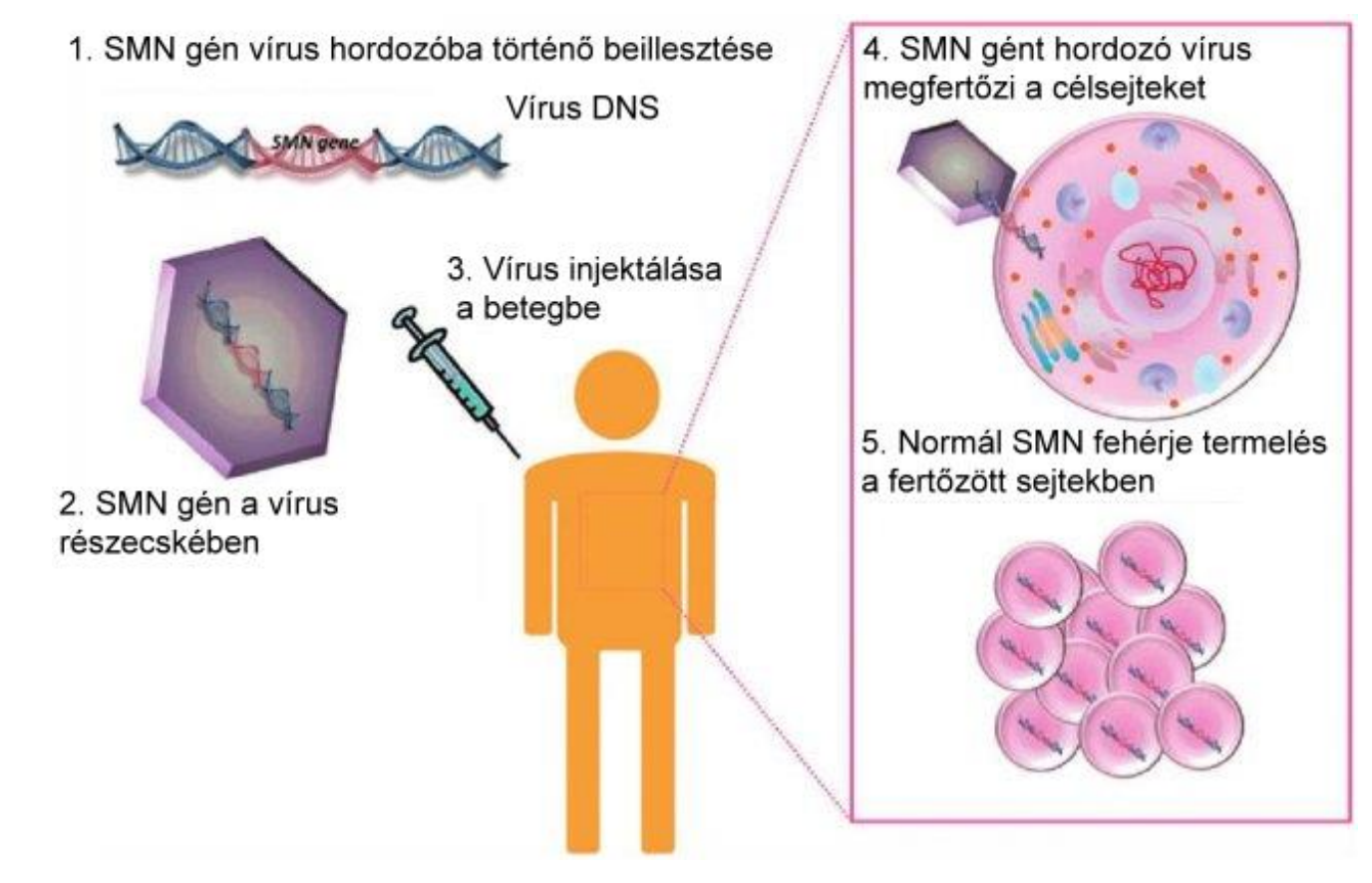

3.ábra: SMA génterápiás kezelés működési elve

Forrás: módosítva https://home.liebertpub.com/publications/human-gene-therapy/19 alapján

\section{EGYÉB FEJLŐDő TECHNIKÁK}

Kísérleti patkányokban vizsgálták a hőstressz hatását vázizom regenerációra [TAKEUCHI et al., 2013]. Az eredmények azt mutatták, hogy a hő sérülés utáni azonnali alkalmazása felgyorsította a sérült hely degenerációs folyamatát, megkönnyítette a makrofágok vándorlását, az SC-k proliferációját és differenciálódását, valamint elősegítette az izomszövet regenerációját.

Az alacsony intenzitású lézerterápiát (LLLT) szintén terápiás lehetőségként tartják számon az izmok javulásának és helyreállításának stimulálására patkányokon végzett állóképességi edzések eredményeinek alapján [ASSIS et al., 2015]. Az LLLT kombinálható vérlemezkékben gazdag vérplazma adásával, ami jobb eredményeket hozott az izmok regenerációjának elősegítésében sérülések után, mint az LLLT önmagában. Egészséges alanyokban megvizsgálták a neuromuszkuláris elektromos stimuláció (NMES) vázizom regenerációjára gyakorolt hatását. A kezelést követően a miogén-prekurzor sejtek (MPC) proliferációja és érett izomrostokkal való fúziója volt megfigyelhető, ami javította a vázizom regenerációs képességét. Az izomkárosodott vagy a VML-lel rendelkező modellekre gyakorolt hatás további vizsgálatokat igényel. 


\section{Krioterápia}

A krioterápia kifejezés minden olyan kezelésre vonatkozik, amely hideg vagy közel fagyos hőmérsékletet (krio = hideg) használ bármilyen módon. Technikai szempontból tartalmazhat jégfürdőt vagy egy hideg zuhanyt. Az orvosok krioterápiát alkalmaznak a szemölcsök lefagyasztására, az ideg-irritáció csökkentésére, a rendellenes bőrsejtek elpusztítására és a malignus elváltozások lokális kezelésére [AMANDA CAPRITTO, 2019]. A hidegterápia alkalmazása 4000 évre nyúlik vissza, mikor már az egyiptomiak hideg hőmérsékletet alkalmaztak a sérülések kezelésére. A technika az idő múlásával tovább fejlődött, és most az emberek a krioterápiát számos formában alkalmazzák, a lokális jégcsomagoktól kezdve a teljes test kriokamráig, mely legfőképp a sportolók körében népszerü [AMANDA CAPRITTO, 2019].

A teljes testet érintő technika folyékony nitrogént használ, ezzel hideg levegôt hozva létre egy kis, zárt kamrában. A hőmérséklet -130 ำ is lehet, éppen ezért 2-4 perces időszakokat ajánlatos kúraszerúen a kamrában tölteni, ellenkező esetben súlyos akár halálos következményekkel kell számolni. A fagyos hőmérséklet túlélési módba kényszeríti a testet, átirányítva a vér áramlását a végtagoktól a központi szervekhez. Amikor az egyén kijut a kamrából, a test felmelegedésével a vér újra normálisan kezd áramlani. A krioterápiás társaságok és a módszert rendszeresen használók szerint ez a keringési terápia tápanyagban ultra gazdag vért juttat az izmokhoz és az ízületekhez [AMANDA CAPRITTO, 2019].

A hidegterápiát a következő betegségekben ajánlják: pikkelysömör, túlsúly, alvászavar, depresszió, asztma, ízületi betegségek. Nem alkalmazható azonban magasvérnyomás, klausztrofóbia, hideg allergia, fél évben belül lezajlott szívinfarktus, daganatos betegségek, súlyos szívritmuszavarok esetén [I01].

A krioterápia előnyei közé tartozik továbbá a gyorsabb edzés utáni regeneráció, a csökkent mértékű gyulladás, a generalizált fájdalomcsillapítás, növekedett rugalmasság, izomgyógyulás, súlyvesztés [AMANDA CAPRITTO, 2019].

Összességében nehéz megmondani, hogy a teljes test-krioterápia valóban biztonságos és hasznos módszer-e. Ezen bizonytalanság hátterében a módszert igazoló bizonyítékok alacsony száma áll. A módszer használatát szintén korlátozza a magas ára.

\section{Mágneses mező}

2019-ben szingapúri tudósok egy csoportja kifejlesztett egy eszközt, amely mágneses mezőt használva segíti elő az izomregenerációt. Az MRegen elnevezésű készülék speciális mágneses tereket alkalmaz az edzés biológiai hatásának kiváltására és felerősítésére, felgyorsítva az izmok helyreállítását (4.ábra) [ASIAN SCIENTIST NEWSROOM, 2019].

Kihasználva azt a tényt, hogy az izomfejlődés energiatermelés által szabályozott, és hogy az energiagazdálkodás és energiaszabályozás rendkívül érzékeny a mágneses terekre, a kutatók egyedülálló mágneses mezőt használtak fel az energiatermelés aktiválására és az 
izmok regenerációjának kiváltására. A mágneses stimuláció révén eloállított energia „becsapja” az izomsejteket olyan módon, hogy azt higgyék, edzés alatt állnak, ennélfogva aktiválva őket. A kutatók több emberi kísérletet elvégezve azt találták, hogy az egészséges egyének, akik hetente egyszer, öt egymást követő héten tíz perces mágneses stimulációt kaptak az MRegen által, átlagosan 30-40 százalékos javulást mutattak mindkét láb izomerejében összehasonlítva azokkal, akik nem kaptak kezelést. A kezelés nemcsak az egészséges alanyok izomteljesítményét javította, hanem kiegészítő kezelésként alkalmazva sérültekben is segítette az izomregenerációt. [ASIAN SCIENTIST NEWSROOM, 2019].
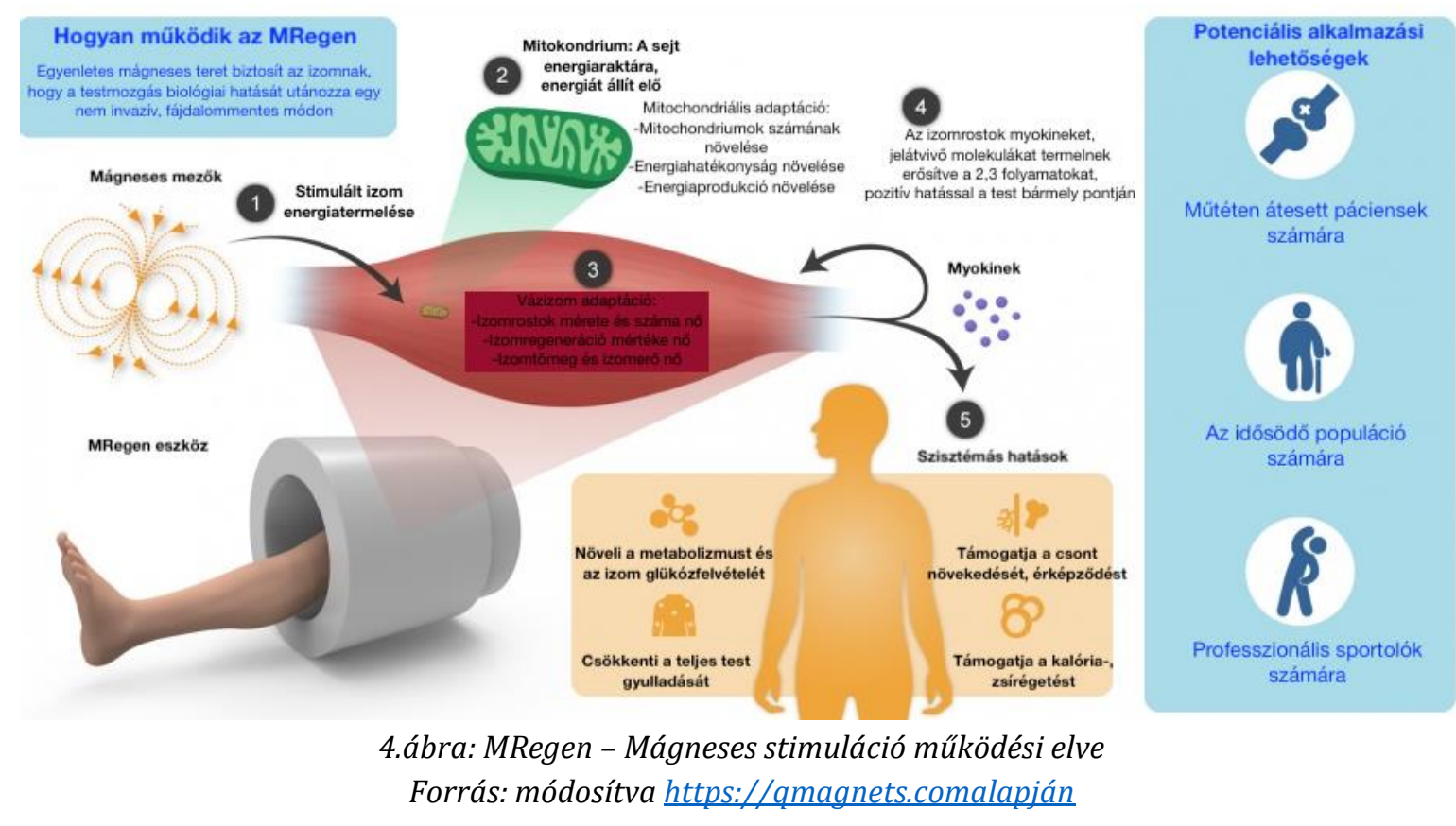

Kimutatták, hogy az izom anyagcseréje (az izom egészségének és a regenerációs képesség egyik legeredményesebb mutatója) akár 50\% -kal javult azokban a betegekben, akik átestek az MRegen kezelésen. Ezenkívül azok, akik mágneses mező kezelést kaptak, nem számoltak be kellemetlen érzésről vagy káros következményekről, bizonyítva, hogy a kezelés fájdalom-, mellékhatásmentes eljárás. A kutatók az eredményeik alapján úgy vélik, hogy a technológia lelassíthatja az izomvesztést és fenntarthatja az egészséges izomanyagcserét időskorúakban, valamint elősegítheti a profi sportolók izomtömegének fenntartását az edzés során.

\section{KIHÍVÁSOK ÉS JÖVőBELI KILÁTÁSOK}

\section{VASZKULARIZÁCIÓ A REGENERÁCIÓ FOLYAMATÁBAN}

Az in vivo izomszövet regenerálódásában, amelyet a biológiailag fejlett izomszövetkonstrukciók segítenek, az azonnali vérellátás hiánya a kudarc egyik fő oka. Az anyagok 
teljes revaszkularizációja akár 3 hétig is eltarthat, ami jelentősen korlátozza a hegnélküli szövetek regenerálódási képességét. A gyors vaszkularizáció képtelensége elkerülhetetlenül sejthalálhoz és legrosszabb esetben a szövet elvesztéséhez vezet [VARKEY et al., 2015].

Ennek a problémának a megoldása elképzelhető a jobb érrendszer kialakulását célzó megközelítésekkel: Az egyik módszer a növekedési faktorok beadása, amely felgyorsíthatja a neoangiogenezist a gyógyulás korai szakaszában [THOMOPOULOS et al., 2010]. Egy másik lehetőség az endothélsejtekkel végzett tenyésztés [HARO et al., 2002]. $\mathrm{Az}$ érrendszeri hálózatoknak a biofejlesztésű anyagokba történő integrálása mikrofluidikus módszerekkel vagy bionyomtatással várhatóan megoldásokat fog nyújtani a közeljövőben [DIVITO et al., 2017].

\section{REGENERÁLÓDOTT IZMOK BEIDEGZÉSE}

A VML-sérülések utáni funkcionális regenerálódás kritikus kérdése az újonnan képződött izomrostok, de novo beidegzése (például neuromuszkuláris csomópontok helyreállítása, NMJ-k); ha ez nem következik be, a regenerálódott izom atrofizál. Az autológ izomtranszplantáció után a direkten vagy idegstimulációt követően kifejtett erő minden esetben gyengébb, mint normális regenerációt követően. Ez a kötőszövet nagyobb mennyiségének és regenerációs elégtelenségnek tudható be. Egy másik kritikus tényező az eredeti NMJ-k gyenge reinnervációja, amely szintén befolyásolja a teljesítményt. Tisztázatlan, hogy a regenerált izmok beépülése milyen mértékben állítható helyre mesterséges módon. Az újonnan regenerált izomrostok NMJ-inek újjáépítéséhez az idegeknek regenerálódni szükséges, új motoros véglemezeket kell kialakítani. A motoros véglemezek nemcsak funkcionális irányítást biztosítanak az újonnan regenerált izmok számára, hanem befolyásolják az izomrostok típusát, alakját és méretét is. A vázizmok reinnerválódására irányuló vizsgálatok eddig az izomsejtek és az idegsejtek in vitro kultúrájára korlátozódtak. Ezek eredményei jobb összehúzó erőt mutattak az ideg-izom konstrukciókban, összehasonlítva a csak izom szerkezetekben mért értékekkel. Azonban az új idegek és motoros véglemezek teljes mértékü helyreállítása az új izmokban nehéznek bizonyult, ez további vizsgálatokat igényel.

\section{IMMUNOLÓGIAI PROBLÉMÁK A BIOLÓGIAI ANYAGOKKAL ÉS SEJTEKKEL}

Az allograftból és a xenograftból származó mátrixot gyakran kilöki a donor szövetben lévő antigének ellen irányuló gazdaszervezeti immunválasz. Az antigén molekulák eltávolítása vagy lefedése céljából ezeket általában decellularizálják és/vagy kémiai keresztkötéseket hoznak létre bennük. A biológiai anyagokon belüli maradvány DNS azonban a decellularizáció után továbbra is indukálhat gyulladásos reakciókat [ZHENG et al., 2005]. A gazdaszervezet biológiai anyagokkal szembeni immunreakciója azon kihívás, amelyet meg kell oldani olyan anyagok tervezésével, amelyek nem idéznek elő ilyen hatásokat, vagy modulálják a káros immunválaszt. Az immunsejtek és a rezidens sejtek közötti kölcsönhatások fontos szerepet játszanak a vázizom regenerációjában. Kimutatták, hogy 
a makrofágok, az eozinofilek és a regulatórikus T-sejtek aktiválják a szatellita sejteket, amelyek hozzájárulnak az izomrostok képződéséhez sérülés után [BURZYN et al., 2013]. A biológiai anyagok tulajdonságainak és az átültetett sejtek immunreakcióinak részletes megértése fontos mérföldkőként szolgálhat a terápiás lehetőségeket és az izomszövetregenerációt célzó kísérletek során. A biológiai anyagok és a sejtek immunmodulációjának vizsgálata adekvát jelátvitellel kombinálva új stratégiákat kínálhat az izomszövet regenerációjának fokozására irányított sejtválasz útján.

\section{MEGBESZÉLÉS}

A vázizom sérülése vagy degenerációja számos klinikai helyzetben előfordul. A sebészeti technikák magasan fejlettek és jó eredményekkel szolgálhatnak az izommúködés helyreállításához. A mútét mindig jelentős kockázattal és magas költségekkel jár, beleértve a sikeres beavatkozásokat is. Ilyenkor az egyik izom jobb múködése érdekében egy másik funkciócsökkenése következhet be. A modern szövetregenerációval és sejtterápiával kapcsolatos kutatások segíthetnek ezen problémák leküzdésében. A szövetregenerációs megoldásoknak olyan biomimetikus anyagokat kell kombinálniuk, amelyek az izomszövet növekedését irányítják növekedési faktorokkal, megfelelő jelátviteli útvonalakkal és releváns sejtekkel. Ezeknek a sejteknek emelniük kell a miogén sejtek mennyiségét a sérült vagy atrófikus izmokban, ami várhatóan elősegíti az izmok regenerálódását. Az effajta kreatív megoldásoknak a funkcionális izomregenerációhoz szükséges regenerációs folyamat (biológiai anyagokra kialakuló sejtválasz, vaszkularizáció, miogenezis és innerváció) mély megértésére kell támaszkodniuk, amely további vizsgálatokat igényel.

A publikáció elkészitését az EFOP-3.6.1-16-2016-00022 „Debrecen Venture Catapult Program" projekt támogatta. A projekt az Európai Unió támogatásával, az Európai Szociális Alap társfinanszírozásával valósult meg.

Dr. Sarang Zsolt elnyerte a Debreceni Egyetem Szodoray Lajos ösztöndíjat. 


\section{IRODALOMJEGYZÉK}

Assis L., Yamashita F., Magri A. M. P., Fernandes K. R., Yamauchi L., \& Renno A. C. M. (2015). Effect of low-level laser therapy (808 nm) on skeletal muscle after endurance exercise training in rats. Brazilian Journal of Physical Therapy, 19, (6), 457-465. doi: 10.1590/bjpt-rbf.2014.0113.

Aurora A., Garg K., Corona B. T., \& Walters T. J. (2014). Physical rehabilitation improves muscle function following volumetric muscle loss injury. BMC Sports Science, Medicine and Rehabilitation. 6, (1, article no. 41) doi: 10.1186/2052-1847-6-41.

Bianchi B., Copelli C., Ferrari S., Ferri A., \& Sesenna E. (2009). Free flaps: Outcomes and complications in head and neck reconstructions. Journal of Cranio-Maxillo-Facial Surgery. 37, (8), 438-442. doi: 10.1016/j.jcms.2009.05.003.

Boontheekul T., Hill E. E., Kong H.-J., Mooney D. J. (2007). Regulating myoblast phenotype through controlled gelstiffness and degradation. Tissue Engineering Part A, 13, (7), 1431-1442. doi: 10.1089/ten.2006.0356.

Brutsaert et al. T. D. (2002). Regional differences in expression of VEGF mRNA in rat gastrocnemius following $1 \mathrm{hr}$ exercise or electrical stimulation. BMC Physiol, 2, 8. doi: 10.1186/1472-6793-2-8.

Burzyn D., Kuswanto W., Kolodin D., et al. (2013). A special population of regulatory T cells potentiates muscle repair. Cell, 155, 1282-1295. doi: 10.1016/j.cell.2013.10.054.

Cerletti M., Jurga S., Witczak C. A., et al. (2008). Highly efficient, functional engraftment of skeletal muscle stemcells in dystrophic muscles. Cell, 134, (1), 37-47. doi:

10.1016/j.cell.2008.05.049.

Cezar C. A., Mooney D. J. (2015). Biomaterial-based delivery for skeletal muscle repair. Advanced Drug Delivery Reviews, 84, 188-197. doi: 10.1016/j.addr.2014.09.008.

Chargé S. B. P., Rudnicki M. A. (2004). Cellular and molecular regulation of muscle regeneration. Physiological Reviews, 84, (1), 209-238. doi: 10.1152/physrev.00019.2003.

DeQuach J. A., Lin J. E., Cam C., et al. (2012). Injectable skeletal muscle matrix hydrogel promotes neovascularization and muscle cell infiltration in a hindlimb ischemia model. European Cells and Materials, 23, 400-412. doi: 10.22203/eCM.v023a31.

DiVito K. A., Daniele M. A., Roberts S. A., Ligler F. S., Adams A. A. (2017). 
Micro fabricated blood vessels undergone angiogenesis. Biomaterials, 138, 142-152. doi: 10.1016/j.biomaterials.2017.05.012.

Finkel R. S., Chiriboga C. A., Vajsar J., et al. Treatment of infantile-onset spinal muscular atrophy with nusinersen: a phase 2, open-label, dose-escalation study. The Lancet. 2016;388(10063):3017-3026. doi: 10.1016/S0140-6736(16)31408-8.

Grasman J. M., Zayas M. J., Page R. L., \& Pins G. D. (2015). Biomimetic scaffolds for regeneration of volumetric muscle loss in skeletal muscle injuries. Acta Biomaterialia, 25, 2-15. doi: 10.1016/j.actbio.2015.07.038.

Grogan B. F., Hsu J. R. (2011). Volumetric muscle loss. American Academy of Orthopaedic Surgeon, 19, S35-S37. doi: 10.5435/00124635-201102001-00007.

Grzelkowska-Kowalczyk K. (2016). The importance of extracellular matrix in skeletal muscle development and function. In: Travascio F., editor. Composition and Function of the Extracellular Matrix in the Human Body.

Guex A. G., Birrer D. L., Fortunato G., Tevaearai H. T., \& Giraud M. N.

Anisotropicallyorientedelectrospunmatriceswith an imprintedperiodicmicropattern: A newscaffoldforengineeredmuscleconstructs. BiomedicalMaterials. 2013;8(2) doi: 10.1088/1748-6041/8/2/021001.021001

Haro H., Kato T., Komori H., Osada M., Shinomiya K. Vascularendothelialgrowthfactor (VEGF)-inducedangiogenesis in herniateddiscresorption. Journal of Orthopaedic Research. 2002;20(3):409-415. doi: 10.1016/S0736-0266(01)00150-4.

Hu L., Klein J. D., Hassounah F., et al. Lowfrequencyelectricalstimulationattenuatesmuscleatrophy in CKD-a potentialtreatmentstrategy. Journal of the American Society of Nephrology. 2015;26(3):626-635. doi: 10.1681/asn.2014020144.

Kalyani R. R., Corriere M., Ferrucci L. Age-related and disease-relatedmuscleloss: theeffect of diabetes, obesity, and otherdiseases. The Lancet Diabetes \&Endocrinology. 2014;2(10):819-829. doi: 10.1016/s2213-8587(14)70034-8.

Kopple J. D., Wang H., Casaburi R., et al. Exercise in maintenancehemodialysispatientsinducestranscriptionalchanges in genesfavoringanabolicmuscle. Journal of the American Society of Nephrology. 2007;18(11):2975-2986. doi: 10.1681/ASN.2006070794. 
Vol 3, No 1 (2020): Stadium - Hungarian Journal of Sport Sciences

https://doi.org/10.36439/SHJS/2020/1/5423

Lee J.-H., Kosinski P. A., Kemp D. M. Contribution of human

bonemarrowstemcellstoindividualskeletalmyotubesfollowedbymyogenicgeneactivation. ExperimentalCell Research. 2005;307(1):174-182. doi: 10.1016/j.yexcr.2005.03.008.

Miller R., Sharma K., Pavlath G., et al. Myoblastimplantation in Duchennemusculardystrophy: The San Francisco study. Muscle\&Nerve. 20(4):469-478. doi: 10.1002/(SICI)1097-4598(199704)20:4<469::AID-MUS10>3.3.C0;2-1.

Parente V., Corti S. Advances in spinalmuscularatrophytherapeutics. TherapeuticAdvances in NeurologicalDisorders. 2018;11:p. 175628561875450. doi: $10.1177 / 1756285618754501$.

Rybalko V. Y., Pham C. B., Hsieh P.-L., et al. Controlleddelivery of SDF-1 $\alpha$ and IGF-1: CXCR4+ cellrecruitment and functionalskeletalmusclerecovery. Biomaterials Science. 2015;3(11):1475-1486. doi: 10.1039/c5bm00233h. doi: 10.1039/C5BM00233H.

Sampaolesi M., Blot S., D'Antona G., et al.

Mesoangioblaststemcellsamelioratemusclefunction in dystrophicdogs. Nature. 2006;444(7119):574-579. doi: 10.1038/nature05282.

Saul D S. A., Kosinsky R. L. Whyagematters: inflammation, cancer and hormones in thedevelopment of sarcopenia. Journal of Osteoporosis and PhysicalActivity. 2017;5(1) doi: 10.4172/2329-9509.1000191.

Saure C., Caminiti C., Weglinski J., de Castro Perez F., Monges S. Energyexpenditure, body composition, and prevalence of metabolicdisorders in patientswithDuchennemusculardystrophy. Diabetes \&MetabolicSyndrome: Clinical Research \&Reviews. 2017 doi: 10.1016/j.dsx.2017.08.006.

Serrano A. L., Muñoz-Cánoves P. Regulation and dysregulation of fibrosis in skeletalmuscle. ExperimentalCell Research. 2010;316(18):3050-3058. doi: 10.1016/j.yexcr.2010.05.035.

Stevanovic M. V., Cuéllar V. G., Ghiassi A., Sharpe F. Single-stageReconstruction of ElbowFlexionAssociatedwithMassiveSoft-

TissueDefectUsingtheLatissimusDorsiMuscleBipolarRotationalTransfer. Plastic and ReconstructiveSurgery - Global Open. 2016;4(9):p. e1066. doi: 10.1097/GOX.0000000000001066.

Su Z., Robinson A., Hu L., et al. Acupuncture plus low-frequencyelectricalstimulation (Acu-LFES) attenuatesdiabeticmyopathybyenhancingmuscleregeneration. PLoS ONE. 2015;10(7) doi: 10.1371/journal.pone.0134511.e0134511 
Vol 3, No 1 (2020): Stadium - Hungarian Journal of Sport Sciences

https://doi.org/10.36439/SHJS/2020/1/5423

Takaoka Y., Ohta M., Ito A., et al.

Electroacupuncturesuppressesmyostatingeneexpression: Cellproliferativereaction in mouseskeletalmuscle. PhysiologicalGenomics. 2007;30(2):102-110. doi:

10.1152/physiolgenomics.00057.2006.

Takeuchi K., Hatade T., Wakamiya S., Fujita N., Arakawa T., Miki A.

Heatstresspromotesskeletalmuscleregenerationaftercrushinjury in rats.

ActaHistochemica. 2014;116(2):327-334. doi: 10.1016/j.acthis.2013.08.010.

Taudorf E. H., Danielsen P. L., Paulsen I. F., et al. Non-

ablativefractionallaserprovideslong-termimprovement of matureburnscars - A

randomizedcontrolledtrialwithhistologicalassessment. Lasers in Surgery and Medicine. 2015;47(2):141-147. doi: 10.1002/lsm.22289.

Thomopoulos et al. S. The effects of exogenousbasicfibroblastgrowthfactoronintrasynovialflexortendonhealing in a caninemodel. J BoneJointSurg Am. 2010;92(13):2285-2293.

Turner N. J., Badylak S. F. Regeneration of skeletalmuscle. Cell and Tissue Research. 2012;347(3):759-774. doi: 10.1007/s00441-011-1185-7.

Turner N. J., Yates A. J., Weber D. J., et al. Xenogeneicextracellularmatrixas an inductivescaffoldforregeneration of a functioningmusculotendinousjunction. TissueEngineering Part A. 2010;16(11):3309-3317. doi: 10.1089/ten.tea.2010.0169.

Varkey M., Ding J., Tredget E. Advances in skinsubstitutes-potential of tissueengineeredskinforfacilitatinganti-fibrotichealing. Journal of FunctionalBiomaterials. 2015;6(3):547-563. doi: 10.3390/jfb6030547.

Wang L., Cao L., Shansky J., Wang Z., Mooney D., Vandenburgh H.

Minimallyinvasiveapproachtotherepair of injuredskeletalmusclewith a shapememoryscaffold. Molecular Therapy. 2014;22(8):1441-1449. doi: 10.1038/mt.2014.78.

Zhang et al. C. Therapy of

Duchennemusculardystrophywithumbilicalcordbloodstemcelltransplantation.

ZhonghuaYiXueYiChuanXueZaZhi. 2005;22(4):399-405.

Zheng M.-H., Chen J., Kirilak Y., Willers C., Xu J., Wood D.

Porcinesmallintestinesubmucosa (SIS) is not an acellularcollagenousmatrix and containsporcine DNA: possibleimplications in human implantation. Journal of BiomedicalMaterials Research Part B: AppliedBiomaterials. 2005;73(1):61-67. doi: 10.1002/jbm.b.30170. 
Vol 3, No 1 (2020): Stadium - Hungarian Journal of Sport Sciences

https://doi.org/10.36439/SHJS/2020/1/5423

\section{Internetes hivatkozás:}

Amanda Capritto, Doescryotherapyworkformusclerecovery? 2019.08.30.

https://www.cnet.com/news/does-cryotherapy-work-for-muscle-

recovery/?fbclid=IwAR0yj9ikzig7tkJUN7JYq28L0HpkfQ09TUd3R53X48n4ZSQZ8V8IJCsj $\underline{\mathrm{VbM}}$

AsianScientistNewsroom, 2019

https://www.asianscientist.com/2019/02/tech/mregen-nus-magnetic-field-musclerepair/?fbclid=IwAR3y2jJHfrq6ALcuWI7SPiUS2ZURsyOHmfPrhxYAyz8U0iMIlMnMLUZ M8Rs

I01: https://hidegkamra.hu/szepsegtitkok/a-hidegterapia-gyogyitohatasai?fbclid=IwAR10e5uNNiSz1dEuT4CbjPX4SmnxZ6HTjDgDmQuR180xk7em6AgIfA72PQ 